\title{
The Role of Internal Audit on Financial Performance Under IIA Standards: A Survey Study of Selected Iraqi Banks
}

\section{Naji Afrasyaw Fatah}

Department of Accounting, College of Administration, Sulaimani Polytechnic University, Sulaymaniyah, Kurdistan Region, Iraq

Naji.afrasyaw@spu.edu.iq

\section{Hawkar Anwer Hamad}

Department of Business and Administration, College of Administration and Economics, Lebanese French University, Erbil, Kurdistan Region, Iraq

hawker.anwar@lfu.edu.krd, hawkarlfu@gmail.com

\section{Khwanas Saeed Qader}

Department of Accounting, College of Administration and Economics, Lebanese French University, Erbil, Kurdistan Region, Iraq

Khowanas.qader@lfu.edu.krd

\section{ARTICLE INFO}

\section{Article History:}

Received:

Accepted: 30/3/2021

Published: Spring 2021

Keywords: Internal audit standards, Financial performance, IIA, Iraqi commercial banks and Kurdistan Region.

\section{ABSTRACT}

This study aimed to demonstrate the importance of internal auditing standards issued by the American Institute of Internal Auditors (IIA) in the financial performance of commercial banks in Iraq. Moreover, the researchers sought to determine the impact of internal audit on financial performance under the standards of the Institute of Internal Auditors (IIA) in the surveyed banks. Furthermore, the study selected managers and auditors in the selected banks. The researchers designed a survey questionnaire and handed over to the target professionals for the data collection as it is the suitable tool and solution to collect data. While for the data analysis, Descriptive analysis and inferential statistical methods were used.

The study fetched the conclusion that the financial performance of commercial banks has a positive affiliation with internal auditing standards. The respondents indicate 
Vol. (6), No (2), Spring 2021

ISSN 2518-6566 (Online) - ISSN 2518-6558 (Print)

Doi:

10.25212/lfu.qzj.6.2.38 that Iraqi commercial banks are still not highly subject to international standards for internal auditing and that all members of the research sample did not agree highly on the statements related to the application of internal auditing standards in their activities. The result of the regression model found that an increase in one unit in internal auditing standards could provide a growth in financial performance. Hence, this study suggests that the Iraqi commercial banks must implement an effective internal audit processes like internal auditing standards in order to improve the financial performances of the banks.

\section{Introduction}

\section{1- Background of study}

The financial humiliations and claims of financial fraud that have occurred recently have emphasized the cons of internal control and internal audit systems in several firms, which led us to pay attention to internal control and internal audit systems and the role of those in the contemporary business firms. Though many researchers have ascribed the failure of the control systems which leads to the weakness of the firms to effectively depend on the internal audit system and not to give importance to the role of this function as a tool seeking the examination and evaluation of the efficiency of financial and organizational performance.

In addition, internal audit procedures and processes have evolved from traditional auditing methods to modern methods emanating from professional societies and the Institute of Internal Auditors in the United States of America, one of the most important of which is the planning and implementation of audit activities, so that the focus of internal audit management efforts is towards more dangerous and important areas In financial institutions.

Since the internal audit works in environments with different goals, sizes and organizations on the one hand, and there is a set of laws and regulations that differ from one country to another, on the other hand, theses modification in the current 
working atmosphere may distress the nature and productivity in executing the duty of any internal auditor, which requires the existence of standards and foundations for control. The function of an internal audit is an attempt to create homogeneity between the results of a business accomplished by the internal auditors, as well as the ability to rely on them more broadly.

The function of an internal audit is primarily preoccupied with evaluating the internal control system in order to make officials control their activities, and this is at all administrative levels. An internal audit is a tool that works to provide management with accurate information to make its decisions and help it in examining and evaluating financial performance. Where the issue of evaluating financial performance is of great importance for any financial or economic institution, especially in this period in which the world witnessed the collapse and bankruptcy of companies and large banks, which among the reasons for its collapse and bankruptcy is a contradiction in the accounting data issued by its real performance. In addition, according to Hamad, $\mathrm{H}$ (2018), the banking sector is one of the most prone industries to threats. This is especially so nowadays given the advancement in technology which has expanded the business into internet banking.

The evaluation of financial performance in Iraqi banks is an urgent necessity due to the large volume of activities practiced by Iraqi banks after the year 2003 . Since then, the requirement of financial performance with an internal audit implementation is the necessary phenomenon to develop the efficiency of the commercial banks. Hence the researchers pursue to govern the impact of internal audit in the Iraqi commercial banks with a keen look at financial performance. Here the researchers examined the internal audit with the discernment of internal audit standards.

\section{2- Internal audit and financial performance}

The definitions dealing with internal auditing varied and developed according to the development of this job, most notably what was issued by The Institute of Internal Auditors in which it stated that it is an autonomous assessment activity that exists to verify and watch closely the operations of accounting and finance in a business 
company to afford the precautionary and curative aids to the managements with in organizing "to fulfill the responsibilities assigned to it with a high degree of efficiency, by providing analysis, evaluation, recommendations, advice and information related to the activities which have audited" (IIA, 2017).

The purpose of the Internal Audit Division in the institutions is to "monitor the plans and follow up their implementation and the extent of achieving the objectives, i.e. reviewing the extent of compliance with the policies, procedures, laws and regulations within the institution" (Ibrahim \& Hussein, 2018). As well as measuring the degree of efficiency with which jobs are executed, enabling the protection of enterprise assets and assessing and controlling risks.

Internal auditing is directed in numerous legal and cultural atmospheres; for organizations that fluctuate in complexity, purpose, structure and size; and by individuals inside or outside of the organization whereas variations might have an effect on the observe of internal auditing in every atmosphere, agreement with the IIA's International Standards. The Internal Auditing (Standards) skill is critical in observing the tasks carried out by the internal auditors especially the activities inside the company by the internal auditors. There are two categories based on the standards: 1. Attribute Standards and 2. Performance Standards. While considering the Attribute Standards, it fulfills the features of the organizations and persons performing the internal auditing.

(a) Attribute Standards

Based on the four main standards issued by the Institute of Internal Auditors, Attribute standards deal with the characteristics of the internal audit companies and entities: Authority, Due Professional Care, Improvement Program, Independence, Objectivity, Proficiency, Purpose, Quality Assurance and Responsibility.

(b) Performance Standards

According to the Institute of Internal Auditors, there are seven Performance Standards those define the activities of the internal audit and customize the 
qualitative measurements in order to assess the performance which includes: Communicating the Acceptance of Risks, Communicating Results, Engagement Planning, Managing the Internal Audit Activity, Monitoring Progress, Performing the Engagement, and The nature of the work.

According to Khanfar et al., (2019) The performance it is a reflection of how the organization uses financial and human resources; And to use them efficiently and effectively in a way that makes them able to achieve goals. As for Drucker (1999) defined performance as a balance between shareholder and worker satisfaction; therefor performance is a measure of judging the extent to which the institution is achieving its main objective, the continuation of its activities in light of competition and it enables it to maintain a balance in provide remuneration for both shareholders and employees. And that the financial performance is a picture that expresses the financial position of the institution to stakeholders.

The financial statements have great merit in evaluating performance, so they must be correct, credible, accurate and prepared in accordance with accounting standards. Hence, the task of the internal auditor begins at the end of the accountant task, which seeks to examine and audit the entirety of the financial statements in order to know the level of performance, profitability and the ability to continue in the future, that is, the expectation of future results.

According to Schiuma (2003), there are three accounting-based indicators to evaluate the firms' (including commercial banks too) performance: Return on Assets (ROA), Return on Equity (ROE), and Return on Investment (ROI). ROA and ROE is used to evaluate the sector performance by the Bank regulators and analysts. It is also used to forecast the inclinations in the market and predicts the failure of the bank by using statistical model.

\section{3- Research problem}


The economic instability has made the banking companies to be more cautious that leads to restrict the new investments. The increasing conditions of uncertainty necessitated serious thinking to find effective ways to improve the financial performance of commercial enterprises and identifying the strengths and weaknesses of the financial performance; This prompted attention to the concept of auditing and its impact on the financial performance of the institution.

As discussed above, the key problems can be found as follows:

To what range internal audit affects financial performance?

\section{4- Research Objectives}

This study aims to:

- The main purpose of this study is to examine if internal audit can actually enhance banks financial performance.

- Determine the role of internal audit on the financial performance of commercial banks in KRG.

- Determine the relation and effect of internal audit on the financial performance of commercial banks in KRG.

\section{Literature Review}

\section{1- Internal Audit Standard}

The researchers (Ibrahim \& Hussein, 2018) aimed to an analytical comparison of internal auditing standards issued by the American Institute of Internal Auditors (IIA) and the guidelines for audit units issued by the Federal Office of Financial Supervision, to show the extent of compatibility and difference between them, and to demonstrate the possibility of applying IIA standards to economic units in Iraq. As this study concluded that the guidebook came in general and did not cover all the work of the internal audit units, and there is a deficiency represented in the failure to keep pace with the changes taking place in the field of internal auditing at the international level and that there is a need to strengthen the guideline in the internal audit 
standards (IIA), which is distinguished by numbers An internal document that contains the objectives, powers, and responsibilities of the internal audit work.

In his study Ondieki (2013), invested the Kenyan commercial banks and presented the solution to regulate "the impact of internal audit on financial performance." Independence of internal auditing system, internal control, internal auditing standards, and professionalism are the perspectives of the internal audit. For his study he selected the first level managers from the financial department as the respondents. His study reveals that the perspectives of the internal audit has a positive relationship that internal audit standards improves the financial performance of the commercialized banks. He further recommended that the Kenyan commercial banks can implement active practices of internal audit like Independence of internal auditing system, internal control, internal auditing standards, and professionalism to improve the financial performances.

Alzeban (2015), determines goal of the study by providing experimental indication of the connection between internal audit and each one of audit committee characteristic through the standards of ISPPIA (International Standards for the Professional Practice of the Internal Audit). The consequences display that the presence of independent members and expertise members in auditing and accounting consequence the internal audit systems by ISPPIA. The conformance that affects $\mathrm{ClA}$ ownership is proved by the CIA.

Cooper, B. J., and et. (2009) investigates the internal audit system in five Asia - Pacific countries (Australia, China, japan, New Zealand and Taiwan) and how do they compile with the international parameters of Institute of Internal Auditors (IIA) for the professional performances and also following the terms and conditions of Internal Audit Activities (IAAs). The differences in the execution are also overlooked among those five countries. Besides arguing the responses among the five countries in their part in the Common Body knowledge of 2006 global study by IIA, the difference between internal audit profile also is discussed. High level usage of standards among 
the respondents from the five country is witnessed. Yet, Australia in following complete compliance with the standards has the largest number of respondents.

\section{2- Independence of Internal Audit}

The study (Burhan Omar, 2018) deal with the impact of internal auditing on the organizational performance of major Jordanian banks. Data were collected through distributed questionnaires on 364 employees was selected for the study and the response analyzed with the help of multiple regression. Internal audit has used as an independent variable while organizational performance was the dependent variable. The analysis of the data revealed that there was a significant impact of internal audit on the organizational performance of most banks. The researcher recommended that there should be more attention by auditors and institutions regulating the audit profession in Jordan towards compliance with audit standards, especially those concerning internal audit and imposing on auditor's responsibility to detect fraud in financial transactions and statements.

Goodwin and Yeo (2013) analyzed for both independence and objectivity that may effect on internal audit. Firstly, the internal audit has influenced organizational independence; there is a relationship with the audit committee. Secondly, use of the function as a management training ground. It is discussed that this training may influence separate objectivity since internal auditors may be reluctant to withstand pressure from an audit. An analysis of chief internal auditors in Singapore was assumed to create current practice in these areas and to recognize the association between these variables. The analysis showed there is a strong association between both of the internal audit committee and the internal audit function the level of interaction seemed greater when the audit committee had comprised solely of independent directors. As a management training ground, the use of internal audit has been found to be well common in Singapore.

\section{3- Internal Control}

Ejoh \& Ejom (2014) chose their study area in cross River College of Education and displays the association between financial performance and internal control activities in the Tertiary Institutions in Nigeria. The researchers used questionnaires for collecting data and also the researcher depended on interview. Regarding control 
activity, the result shows that. The study displays that the top management initiates all the college's activities. The study also reveals that regarding control activities, there is a huge relational gap between the high-level officers and the Accounting and Finance department of the institution. Furthermore, the study shows that the external auditor has audited financial statements annually. Even though the institution observes strictly with the provisions of the annual budgets by the various departments, the controls are not placed properly which results in exceeding of incurring expenditure. The study suggested that the management should prepare a fixed training for their staff on control mechanism.

Kinyua and et. (2015) in their research work asserts that management, governance and other personnel arranges realistic assurance with the internal controls which aims at procedures, affects the entity's objectivity and the achievement in accordance with the reliability of financial reporting and the efficiency and effectiveness of procedures in following the rules and regulations of the compliance institution. Internal control has the main role of every organization about its financial performance goal. The study tries to investigate the Nairobi Securities Exchange and determines that internal control systems are influenced by the companies in their financial performances. The selected companies in Kenya were analyzed to achieve the objective of their study on the financial performances like internal audit, internal controls, control environment, risk management, etc. The study concluded there is a significant relationship between the internal control environment and financial performance. Further the suggestions were provided that to progress in the financial performances the companies have to increase the internal control environment cited in the Nairobi Securities Exchange.

\section{4- Professional competence}

Abbott and et. (2015) they taking note of the importance of internal audit function (IAF) and the researchers depended on archival evidence on internal audit quality, the researchers survey an interactive model of IAF quality (comprised of competence and independence) to better comprehend the determines of IAF effectiveness as a financial reporting monitor. To cut a long story short, the responds display that, the 
answer to " what is the effect of internal audit competence (independence) on financial reporting quality?" is "it depends on the independence (competence) of the internal auditor". The analysis shows that the hypotheses that the joint each one of the competences and independence is a very important and necessary antecedent to effective IAF financial reporting monitoring. The study expands the comprehension of IAF quality determinants in the kingdom of financial reporting as it relates to in progress debates by researchers, standard setters, regulators, and practitioners.

Carey and et. (2006) researched examines to indicate the internal audit outsourcing in 99 companies by survey data which are listed on the Australian Stock Exchange, the responds from logistic regression analyses recommend that internal audit outsourcing is related with perceived cost savings and the technical competence of the external provider. For a subsample of companies that have at an earlier time take on internal audit activities before subcontracting, country to suspects, the bigger the organization the greater the disposition to outsource. Moreover, smaller companies are reaching to be approving internal audit for first time, through outsourcing. These responds recommend that internal audit outsourcing is a growing business chance for professional accountants; then 75 percentages of companies outsourcing to their external auditor, there are implications for external auditor independence.

\section{Research Methodology}

\section{1- Population and sample}

The study population is represented by a group of commercial banks operating in the Kurdistan Region, that are licensed by the Central Bank of Iraq. The study sample consists of managers and internal audit cadres in surveyed banks.

\section{2- Data collection and Analytical Model}

For each of the target populations, the researchers have created the questionnaire and individually administered the questionnaires to selected workers of commercial banking institutions. The technique of data analysis was used for both quantitative analysis and regression analysis. The data were analyzed with SPSS. To conduct data processing, the following regression model was used: 
$\operatorname{PERF}=\beta 0+\beta 1 \mathrm{IAS}+\varepsilon$

Where; PERF = financial performance of the bank

IAS = Internal Audit Standards

According to financial performance metrics, including the profitability of the bank, the banks' performance is reasonably good (ROA). For internal audit criteria, the accuracy of the results was tested in terms of quality agreed by the survey.

\section{3- Research Hypotheses}

Based on the literature review presented formerly, the researchers consider the following hypotheses, for achieving the objectives of the research:

$\mathrm{H} 1$ : There is no significant relationship between the application of internal auditing standards and financial performance

$\mathrm{H} 2$ : The internal auditing standards has no effects on the financial performance

\section{Findings}

This part consists of the results of the statistical analysis of the study sample responses.

1- Descriptive Statistics: At the outset, we refer to the results of the statistical description of the respondents 'estimates on the extent of application of internal auditing standards in the researched banks and the extent to effects internal audit standards on the financial performance of the bank from perspective of respondents. 


\section{QALAAI ZANISTSCIENTIFIC JOURNAL}

A Scientific Quarterly Refereed Journal Issued by Lebanese French University - Erbil, Kurdistan, Iraq

Vol. (6), No (2), Spring 2021

ISSN 2518-6566 (Online) - ISSN 2518-6558 (Print)

\section{Table (1) Descriptive Statistics of the Internal audit standards statements}

\begin{tabular}{|l|l|l|l|}
\hline Terms & N & Mean & $\begin{array}{l}\text { Std. } \\
\text { Deviation }\end{array}$ \\
\hline $\begin{array}{l}\text { 1- Whether standards for audits and audit- related services did affect } \\
\text { performance in our organization }\end{array}$ & 92 & 3.70 & 0.937 \\
\hline $\begin{array}{l}\text { 2- Effectiveness of auditing was as a result of performing auditing work according } \\
\text { to the set internal audit standards }\end{array}$ & 92 & 3.18 & 0.661 \\
\hline $\begin{array}{l}\text { 3- The auditors in our organization objectively performed their roles and adhered to } \\
\text { the accepted professional standards and practices. }\end{array}$ & 92 & 3.17 & 0.683 \\
\hline $\begin{array}{l}\text { 4- The formal auditing standards in our bank recognized that, other than financial } \\
\text { reports, internal auditors should provide related services on other information. }\end{array}$ & 92 & 2.70 & 1.073 \\
\hline $\begin{array}{l}\text { 5- The internal audit in our bank evaluates and contributes to governance, risk } \\
\text { management and control effectiveness by use of a systematic and disciplined } \\
\text { approach. }\end{array}$ & 92 & 2.22 & 1.278 \\
\hline 6- The internal audit in our bank reports to the Board of Directors & 92 & 3.07 & 0.937 \\
\hline $\begin{array}{l}\text { 7- Internal audit in our firm is independent of both the personnel and other } \\
\text { operational activities within the firm }\end{array}$ & 92 & 3.18 & 0.661 \\
\hline $\begin{array}{l}\text { 8- The essence of auditing in our firm is independence } \\
\text { 9- The auditors in my bank are qualified to undertake audit functions }\end{array}$ & 92 & 3.17 & 0.683 \\
\hline
\end{tabular}

\begin{tabular}{|l|r|r|r|}
\hline 10- Professionalism is strongly emphasized within my bank & 92 & 2.22 & 1.278 \\
\hline $\begin{array}{l}\text { 11- In our firm frauds are identified by the internal audit function } \\
\text { 12- Internal audit reports are prepared and reviewed timely by the audit committee }\end{array}$ & 92 & 3.17 & 0.683 \\
\hline $\begin{array}{l}\text { 13- Internal audit recommendations touching on significant risk areas are } \\
\text { implemented immediately }\end{array}$ & 92 & 2.25 & 1.278 \\
\hline $\begin{array}{l}\text { 14- The local environment has the ability to adapt to the IIA standards for internal } \\
\text { auditing }\end{array}$ & 92 & 3.07 & 0.937 \\
\hline $\begin{array}{l}\text { 15- IIA standards of internal audit are able to enhance the efficiency of the } \\
\text { organization's performance }\end{array}$ & 92 & 3.18 & 0.661 \\
\hline General Mean & & 2.912 \\
\hline
\end{tabular}

Table No. (1) shows the arithmetic mean and standard deviation of the independent variable (internal audit standards). This variable was measured in the questionnaire through questions 1--15 in Section B. 


\section{QALAAI ZANISTSCIENTIFIC JOURNAL}

A Scientific Quarterly Refereed Journal Issued by Lebanese French University - Erbil, Kurdistan, Iraq

Vol. (6), No (2), Spring 2021

ISSN 2518-6566 (Online) - ISSN 2518-6558 (Print)

We notice that the arithmetic means of the paragraphs related to this variable ranges between 2.22 and 3.70. This indicates that Iraqi commercial banks are still not highly subject to international standards for internal auditing and that all members of the research sample did not agree highly on the statements related to the application of internal auditing standards in their activities and in some cases, were the average answers of them less than the acceptable mean, i.e. less than 2.5, or they were neutral in giving a complete opinion about it. so, there is a deficiency in internal control activity that is Iraqi banks are not keeping pace with the changes taking place in the field of internal auditing at the international level and there is a need to strengthen the guidelines in the internal auditing standards (IIA), and this is consistent with the findings of the researchers (Ibrahim \& Hussein, 2018). 


\section{Table (2) Descriptive Statistics of the financial performance statements}

\begin{tabular}{|l|l|l|l|}
\hline \multicolumn{1}{|c|}{ Terms } & N & Mean & \multicolumn{1}{|c|}{$\begin{array}{c}\text { Std. } \\
\text { Deviation }\end{array}$} \\
\hline $\begin{array}{l}\text { 1- Internal audits standards affect the financial performance of } \\
\text { commercial banks in Iraq. }\end{array}$ & 4.07 & 0.537 \\
\hline $\begin{array}{l}\text { 2- Professional competence of internal auditor affects the financial } \\
\text { performance of commercial banks in Iraq. }\end{array}$ & 4.18 & 0.461 \\
\hline $\begin{array}{l}\text { 3- Internal controls affect the financial performance of commercial banks in92 } \\
\text { Iraq. }\end{array}$ & 4.17 & 0.483 \\
\hline $\begin{array}{l}\text { 4- Independence of Internal Audit affects the financial performance of } \\
\text { commercial banks in Iraq. }\end{array}$ & 92 & 4.70 & 0.433 \\
\hline $\begin{array}{l}\text { 5- The internal control system is effective in minimizing potential losses in } \\
\text { the institution. }\end{array}$ & 92 & 4.22 & 0.478 \\
\hline $\begin{array}{l}\text { 6- Financial performance in our firm is affected by fraudulent activities and } \\
\text { fraud detection which are inherently not easy to predict and detect. }\end{array}$ & 92 & 4.07 & 0.537 \\
\hline $\begin{array}{l}\text { 7- The achievement of the function and objective of the internal audit has } \\
\text { resulted to effectiveness in our firm. }\end{array}$ & 92 & 4.18 & 0.461 \\
\hline
\end{tabular}

\begin{tabular}{|l|l|l|l|l|l}
\hline 8- Internal audits standard affect the financial performance of commercial & 92 & 4.17 & 0.483
\end{tabular} banks in Iraq.

9- Professional competence of internal auditor affects the financial 92 performance of commercial banks in Iraq.

10- Internal controls affect the financial performance of commercial banks 92 in Iraq.

11- Independence of Internal Audit affects the financial performance of 92 commercial banks in Iraq.

12- The internal control system is effective in minimizing potential losses in 92 the institution.

13- Financial performance in our firm is affected by fraudulent activities and 92 fraud detection which are inherently not easy to predict and detect.

14- The Internal Audit Department and the Finance Department cooperate 92 in the field of information exchange, especially with regard to investments and banking operations, to improve their financial performance

15- The implementation of IIA standards contributes to the internal audit in 92 enhancing the financial performance by evaluating and diagnosing the financial condition of the bank

\begin{tabular}{|l|l}
\hline 4.17 & 0.483 \\
\hline 4.70 & 0.433 \\
\hline 4.22 & 0.478 \\
\hline 4.17 & 0.483 \\
\hline 4.70 & 0.433 \\
\hline 4.22 & 0.478 \\
\hline 4.07 & 0.537 \\
\hline 4.17 & 0.483 \\
\hline 4.2673
\end{tabular}




\section{QALAAI ZANISTSCIENTIFIC JOURNAL \\ A Scientific Quarterly Refereed Journal Issued by Lebanese French University - Erbil, Kurdistan, Iraq \\ Vol. (6), No (2), Spring 2021 \\ ISSN 2518-6566 (Online) - ISSN 2518-6558 (Print)}

Table No. (2) Shows the arithmetic mean and standard deviation of the importance and influence of the independent variable on the dependent variable (financial performance). This variable was measured in the questionnaire through questions 1 to 15 in Section C.

Note that the arithmetic means of the paragraphs related to this variable range between 4.07 and 4.70. This indicates the awareness of workers in Iraqi banks of the importance of internal auditing and its impact on financial performance, as they agreed in parallel to the paragraphs related to financial performance, the general mean of their response was estimated at (4.2673) that indicate to they have concluded that internal audit standards, independence of internal auditing, professionalism and internal control have a positive relationship with the financial performance of commercial banks.

2-Inferential statistics: Since our study includes independent variable and dependent variable, and to test the extent of the impact of the dependent variable, which is (internal audit standards) on the dependent variable (financial performance) and also in order to test relations between variables, we have relied on the regression model and correlation coefficient to get the desired results to achieve the goals of the study and allow us to test a hypotheses.

Table (3) Model Summary

\begin{tabular}{|l|l|l|l|l|}
\hline Model & $R$ & R Square & $\begin{array}{l}\text { Adjusted } \\
\text { Square }\end{array}$ & $\begin{array}{l}\text { Std. Error of the } \\
\text { Estimate }\end{array}$ \\
\hline 1 & $.819^{a}$ & .740 & .728 & .31263 \\
\hline
\end{tabular}

Simple linear regression has used to check the effect of internal audit standards (independent variable) on financial performance (dependent variable). Table ( 3 and 4) show the regression model and correlation coefficient of variables. According to the model summary, the $R$ (correlation Coefficient) gives a positive value of 0.819 this indicates that there exists a significant positive correlation between internal audit standards and financial performance. The value of adjusted $R$ square is 0.728 which means 72.8 per cent variation in financial performance is explained by the internal audit. This shows that $72.8 \%$ changes in the financial performance of commercial banks could be accounted for by changes in internal audit standards and the rest of 
Vol. (6), No (2), Spring 2021

ISSN 2518-6566 (Online) - ISSN 2518-6558 (Print)

the variation (1-R2) is an unexplained variation by this study. According to table (4), the significant level (P-value) in the independent variable (Internal Audit Standards) is 0.003 and it means the result less than 0.05 . Hence, (IAS) has a positive effect on Financial Performance.

\begin{tabular}{|c|c|c|c|c|c|c|}
\hline \multicolumn{7}{|c|}{ Table 4 Coefficients $^{a}$} \\
\hline & \multirow[t]{2}{*}{ Model } & \multicolumn{2}{|c|}{$\begin{array}{l}\text { Unstandardized } \\
\text { Coefficients }\end{array}$} & \multirow{2}{*}{$\begin{array}{c}\begin{array}{c}\text { Standardized } \\
\text { Coefficients }\end{array} \\
\text { Beta } \\
\end{array}$} & \multirow[t]{2}{*}{$\mathrm{T}$} & \multirow[t]{2}{*}{ Sig. } \\
\hline & & $\mathrm{B}$ & Std. Error & & & \\
\hline \multirow{2}{*}{1} & (Constant) & .264 & .565 & & $\begin{array}{c}2.77 \\
8\end{array}$ & .010 \\
\hline & Internal Audit Standards & .381 & .256 & .324 & $\begin{array}{c}3.21 \\
0\end{array}$ & .003 \\
\hline
\end{tabular}

From the above results and by applying the simple regression equation we conclude the following:

$Y=\beta_{0}+\beta_{1} \mid A S+\varepsilon$

PERF $=0.264+0.381 *$ IAS

In the same report, we found that retaining internal audit standards at a constant level of 0,264 would contribute to a unit improvement in the internal auditing standards contributing to an increase in commercial bank's financial results of 0,381.

\section{Conclusion}

After analyzing the data, we can now test the validity of the hypotheses so that we can accept or reject the null hypothesis depending on the results obtained from the correlation and regression tests. 


\section{QALAAI ZANISTSCIENTIFIC JOURNAL}

A Scientific Quarterly Refereed Journal Issued by Lebanese French University - Erbil, Kurdistan, Iraq

Vol. (6), No (2), Spring 2021

ISSN 2518-6566 (Online) - ISSN 2518-6558 (Print)

Table (5) Summary of Hypothesis Analysis

\begin{tabular}{|c|c|c|}
\hline $\begin{array}{c}\text { Proposed } \\
\text { Hypotheses }\end{array}$ & Descriptive of proposed Hypotheses & Results \\
\hline H1 & $\begin{array}{c}\text { There is no significant relationship between the application of } \\
\text { internal auditing standards and financial performance }\end{array}$ & Rejected \\
\hline H2 & $\begin{array}{c}\text { The internal auditing standards has no effects on the financial } \\
\text { performance }\end{array}$ & Rejected \\
\hline
\end{tabular}

Moreover, the study showed variation in the financial performance of commercial banks due to changes in internal auditing standards. This indicates that the fluctuation in the financial performance of commercial banks can be explained by changes in internal auditing standards, so the more the banks' management makes improvements in its control activities, the higher the level of their financial performance. In view of the responses of the study sample and the results of the regression, the study showed a strong positive relationship between the financial performance of commercial banks and the adoption internal auditing standards. Hence, all variables related to audit activities effected on the financial performance.

\section{Recommendations}

The results indicate that Iraqi commercial banks are still not highly subject to international standards for internal auditing. So, in order to improve the role and importance of internal auditing in financial performance, we recommend that the Central Bank of Iraq establish an institute for the development of internal auditors, and commercial banks in Iraq should adopt effective internal audit practices such as internal auditing standards to enhance the financial performance of banks, also gives training courses for qualified auditors to raise their efficiency. The management of the researched institutions should encourage auditors. The banks must support the independence of internal auditors from some factors influences in order to be able to carry out their duties to the fullest, which reflects positively on the financial performance. 


\section{QALAAI ZANISTSCIENTIFIC JOURNAL \\ A Scientific Quarterly Refereed Journal Issued by Lebanese French University - Erbil, Kurdistan, Iraq \\ Vol. (6), No (2), Spring 2021 \\ ISSN 2518-6566 (Online) - ISSN 2518-6558 (Print)}

\section{A recommendation for future studies}

This research recommends conducting a similar study, but with a focus on commercial banks in other Iraqi cities outside the governorates of the Kurdistan region. There is a need to conduct studies on money laundering operations and accusations of corruption directed at Iraqi banks, as well as identifying the challenges facing internal auditing in commercial banks. All this will help enhance internal auditing in Iraqi commercial banks and thus positively affect their performance.

\section{REFERENCES:}

Abbott, L. J., Daugherty, B., Parker, S., \& Peters, G. F. (2016). Internal audit quality and financial reporting quality: The joint importance of independence and competence. Journal of Accounting Research, 54(1), 3-40.

Ahmad, B.O. (2018). The Effect of Internal Audit on Organizational Performance: An Empirical Exploration of Selected Jordanian Banks. Research Journal of Finance and Accounting, Vol.9, No.14, 2018.

Alzeban, A. (2015). Influence of audit committees on internal audit conformance with internal audit standards. Managerial Auditing Journal.

Carey, P., Subramaniam, N., \& Ching, K. C. W. (2006). Internal audit outsourcing in Australia. Accounting \& Finance, 46(1), 11-30.

Cooper, B. J., Leung, P., Dellaportas, S., Leung, P., \& Cooper, B. J. (2009). Internal audit-an Asia-Pacific profile and the level of compliance with Internal Auditing Standards. Managerial Auditing Journal.

Ejoh, N., \& Ejom, P. (2014). The impact of internal control activities on financial performance of tertiary institutions in Nigeria. Journal of Economics and Sustainable Development, 5(16), 133-143.

Goodwin, J., \& Yeo, T. Y. (2001). Two factors affecting internal audit independence and objectivity: Evidence from Singapore. International Journal of Auditing, 5(2), 107-125.

HAMAD, H. CUSTOMER SATISFACTION IN BANKING SECTOR: THE CASE IN NORTH IRAQ, CITY OF ERBIL. 


\section{QALAAI ZANISTSCIENTIFIC JOURNAL}

A Scientific Quarterly Refereed Journal Issued by Lebanese French University - Erbil, Kurdistan, Iraq

Vol. (6), No (2), Spring 2021

ISSN 2518-6566 (Online) - ISSN 2518-6558 (Print)

Ibrahim, M. A. \& Hussein, H. F. (2018). Identifying the similarities and differences between the internal audit standards and the internal audit units work guide in Iraq. Journal of Accounting and Financial Studies, 13 (43).

Kinyua, J. K., Gakure, R., Gekara, M., \& Orwa, G. (2015). Effect of internal control environment on the financial performance of companies quoted in the Nairobi Securities Exchange. International Journal of Innovative Finance and Economics Research, 3(4), 29-48.

Ondieki, N. M. (2013). Effect of internal audit on financial performance of commercial banks in Kenya (Doctoral dissertation, University of Nairobi).

Stewart, J., \& Subramaniam, N. (2010). Internal audit independence and objectivity: emerging research opportunities. Managerial auditing journal.

\section{كاريكهريى وردبينيى ناوخوّيى لهسهر ئهداي دارايى بهيّيى ستانداردهكانى يهيمانكهى نيّودهولّهيى وردبينانى ناوخوّيى (IIA): تويّزينه وهيه له بانكه عيّراقييه ههلِّزَيْردراوهكان}

يـوخـــه:

ئامانجى ئهم تويّزينهوهيه بريتيبوو له رِوونكردنهوهى رِوّلّى ستانداردهانى وردبينيى ناوخوّيى كه لهلايهن يهيمانكهى نيّودهولّهتيى وردبينانى ناوخوّيى (IIA) دهرجويَنراوه، لهسهر ئهداى دارايى بانكه بازركانييه عيّراقييهكان. تويّزهرهكان ههولّيانداوه لهزيّر روّشنايى يهيمانكهى نيّودهولَهتيى وردبينانى ناوخوّيى (IA)دا كاريكهريى وردبينيى ناوخوّيى لهسهر ئهداى دارايى بانكه بازرگانييهكانى عيّراق دهستنيشان بكهن. تويّزينهوهكه بهريّوهبهران و وردبينانى بانكهكانى وهك نمونه ههلِّزاردووه، و و لهريّكهى ئامادهردنى فوّرمى رِاوهرگرتنهوه رِاى كوّمهلّكهى تويّزينهوهكهيان وهرگرتووه، جونكه باشترين و كونجاوترين ئامرازى كوّكردنهوهى زانيارييه. ههروهها شيكاريى وهسفى و تيّستهكانى يهيوهندى (Correlation) و جهماوه (Regression) وهك ريّكًاى شيكاريى داتاكان بهكارهيّنراون. 


\section{QALAAI ZANISTSCIENTIFIC JOURNAL}

A Scientific Quarterly Refereed Journal Issued by Lebanese French University - Erbil, Kurdistan, Iraq

Vol. (6), No (2), Spring 2021

ISSN 2518-6566 (Online) - ISSN 2518-6558 (Print)

دهرهنجامهكانى تويّزينهوهكه بريتيبوون لهوهى كه ستانداردهكانى وردبينيى ناوخوّيى يهيوهندييهكى ئهرينيى به ئهداي دارايى بانكه بازركانييهكانهوه ههيه. ههروهها وهلامدهرووهكان ئامازهيان بهوهداوه كه هيّشتا بانكه بازرگانييهكانى عيّراق بهشيّوهكى بهرجاو ملكهجى ستاندارده نيّودهولَّهييهكانى وردبينيى ناوخوّيى نهبوون، و سهرجهم تاكهانى ساميلّى تويّزينهوهكه بهتهواويى رِزامهندييان لهسهر ئهو يرسيارانه دهرنهبريوه كه يهيوهنديى به جيّبهجيَكردنى ستانداردهانى وردبينيى ناوخوّييهوه ههيه له كاروجالاكييهكانياندا. ههوهها تويّزينهوهكه گهيشتووه بهو ئهنجامهى كه زيادكردنى ههر يهكهيهك له ستانداردهكانى وردبينيى ناوخوّيى دهبيّته هوّى بهرزبوونهوهى ئهداى دارايى. له كوّتاييدا تويَزينهوهكه به جهند رِاسياردهيهك دهرجووه، گرنكترينيان بريتييه لهوهى كه يِيويسته بانكه بازركانييهكانى عيّراق ريّكاريّكى كارا و جالاكى وهك ستانداردهانى وردبينيى ناوخوّيى

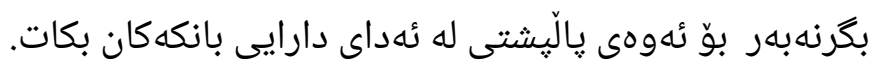
وشه سهرهكييهكان: ستانداردهانى وردبينيى ناوخوّيى، ئهداى دارايى، يهيمانكهى نيّودهولّهيى وردبينانى ناوخوّيى (IIA)، بانكه بازركانييه عيّراقييهكان، ههريّمى كوردستان.

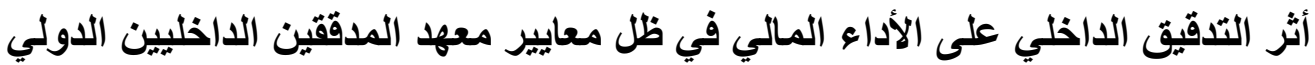 (IIA)}

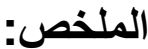

هدفت هذه الدر اسة إلى نوضيح أهمية معايير المر اجعة الداخلية الصادرة عن المعهد الأمريكي للمدققين الداخليين

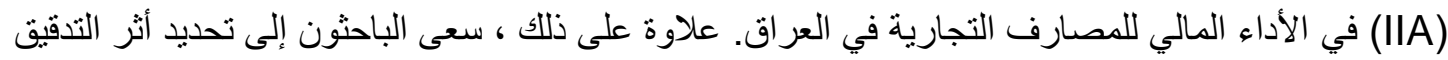

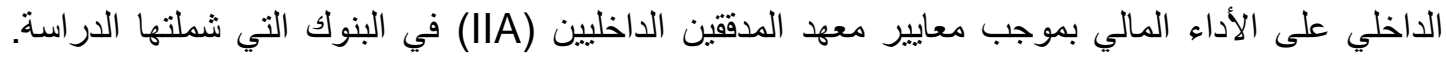

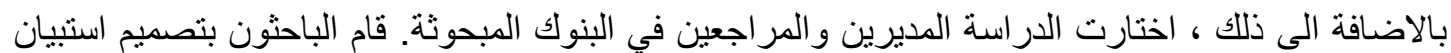

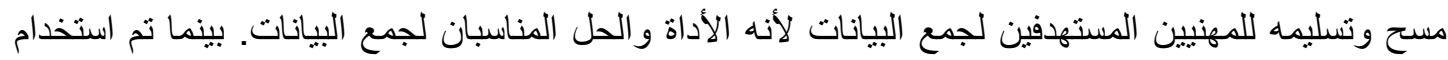

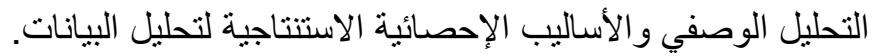

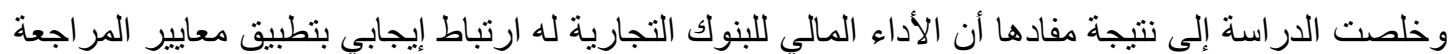

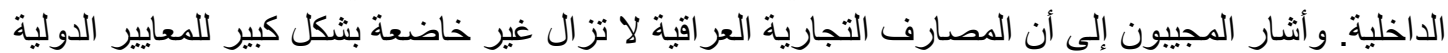

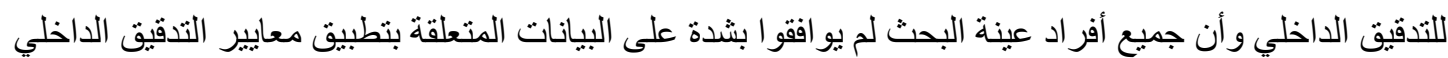




\section{QALAAI ZANISTSCIENTIFIC JOURNAL}

A Scientific Quarterly Refereed Journal Issued by Lebanese French University - Erbil, Kurdistan, Iraq

Vol. (6), No (2), Spring 2021

ISSN 2518-6566 (Online) - ISSN 2518-6558 (Print)

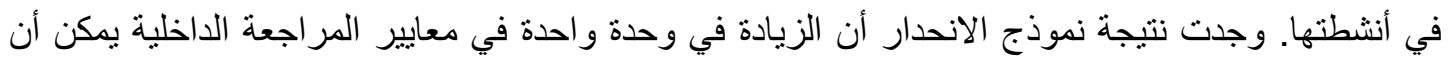

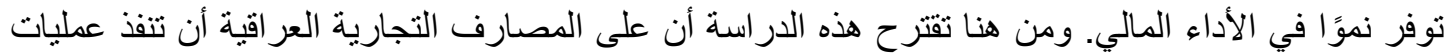

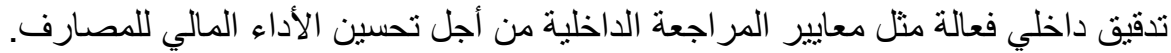

الكلمات المفتاحية: معايير التدقيق الداخلي ، الأداء المالي ، معهد المدققين الداخليين (IIA) ، البنوك التجارية

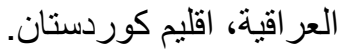

